Heath, M. K., MacQueen, J. W. \& Spies, T. D. (1940). Science, 92, 5 I4.

Latimer, H. B. \& Ibsen, H. L. (I932). Anat. Rec, 52, I.

Mackay, H. M. M. (1921). Biochem. F. 15, 19.

Morris, M. L. (1953). Vet. Med. 48, 45 I.

Phillips, P. H. \& Hart, H. B. (I935). F. biol. Chem. rog, 657.

Pottenger, F. M. (1946). Amer. $\mathscr{F}$. Orthodont. 32, 467.

Pottenger, F. M. \& Simonsen, D. G. (1939). F. Lab. Clin. Med. 25, 238.

Robinson, H. E. (1947). In Appraisal of Human Dietaries by Animal Experiment, p. 4I. [R. R. Williams, editor.] New York: Williams Waterman Foundation.

Saunders, J. A. (1953). F. Physiol. 121, 12P.

Scott, P. P. (1952). F. Physiol. x18, 35P.

Scott, P. P. (1957). In UFAW Handbook on the Care and Management of Laboratory Animals, 2nd ed., chapter 46. [A. N. Worden and W. Lane-Petter, editors.] Tunbridge Wells: Courier Publishing Co. (In the Press.)

Scott, P. P. \& Lloyd-Jacob, M. A. (1955). Stud. Fertil. 7, 123.

Smith, D. C. \& Proutt, L. M. (1944). Proc. Soc. exp. Biol., N.Y., 56, I.

\title{
The role of an adequate diet in the production of healthy guinea-pigs
}

\section{By J. Stuart Paterson, Ministry of Supply Establishment, Allington Farm, Porton Down, Salisbury, Wilts}

An adequate diet for a laboratory guinea-pig does not suddenly become a matter of importance because that animal has just been included in an experimental group: it is important that the animal should have received proper nourishment in its earlier life and it was equally important that its mother had been properly fed. If we make an exception for certain nutritional studies which involve the manipulation of the diet of the pregnant animal then $I$ think one must agree that the proper nutrition of the expectant and lactating mother is as important as the proper feeding of the growing young. The production of healthy guinea-pigs, as with other species, depends upon two primary considerations, adequate diet and suitable environment and, of these, I consider diet to be the more important. Quite reasonable guineapigs may be produced under poor environmental conditions but I doubt if firstclass animals are ever produced where the diet is faulty.

At a symposium such as this, I feel a little diffident in drawing attention to the paucity of information on the exact nutritional requirements of the guinea-pig, but, nevertheless, I think we know sufficient to provide an adequate diet for them. The guinea-pig is a vegetarian by nature and will thrive on a wide variety of diets provided care is taken to include adequate amounts of fresh vegetable food to provide the animal with a sufficient amount of vitamins $\mathrm{C}$ and $\mathrm{E}$, and sufficient hay to provide an, as yet, unidentified factor. A guinea-pig will consume quite prodigious quantities of these two basic feeding-stuffs-even up to a third or a half of its own body-weight of vegetables daily particularly if water is not readily available. Guineapig fanciers have long realized that it was necessary to supplement this simple diet with some form of concentrate if regular breeding and a reasonable survival rate of youngsters was to be achieved. For many decades, fanciers and the laboratories breeding guinea-pigs employed as a concentrate a mixture consisting of one part 
of bran with two parts of crushed oats fed either dry or slightly damped. This was somewhat improved by the substitution of dried sugar-beet pulp for oats, but as the beet had to be soaked overnight in water before being 'dried off' with the bran, the resulting mixture frequently went sour unless it was consumed promptly. With these diets, however, breeding results were poor and in a series of observations I made in $194 \mathrm{I}^{-2}$, on a small colony of the Dunkin-Hartley strain on a bran and oat diet, I found that one-hundred unselected litters averaged 2.9 born and 2.5 weaned per litter, the birth weight averaged $85 \mathrm{~g}$ and the weaning weight, at 21 days, was only I $84 \mathrm{~g}$. Bruce $\&$ Parkes (1947), in their studies on the nutrition of laboratory animals, pointed the way to a more adequate diet by the inclusion of protein of both animal and vegetable origin in their pelleted concentrate diet. Lane-Petter (1957) and Cassidy (1957) have already discussed the preparation and use of pelleted diets, but I would like to ask nutritionists and others publishing the formulas of such diets to be as precise as possible and to give each ingredient its appropriate trade description. For example, to simply write 'grass meal' is not sufficient, for poorquality grass meal may be little more than ground hay and contain as little as $8 \%$ protein and only a little carotene, whereas it might well have been a very high-quality lucerne or alfalfa meal containing anything up to $24 \%$ protein and upwards of $25^{\circ}$ $\mathrm{mg}$ carotene $/ \mathrm{kg}$ besides quite a useful vitamin $\mathrm{C}$ content.

Compounders making pellets for the guinea-pig colonies at Porton are required to work to the formula given in Table $\mathbf{I}$.

\section{Table I. Parkes's diet I8 (modified)}

(See Bruce \& Parkes, I947)

\begin{tabular}{lr} 
English fine wheatfeed & $\%$ \\
Finely ground grass meal containing not less than $250 \mathrm{mg} / \mathrm{kg}$ carotene & 15 \\
$\quad$ (see note I) & 30 \\
Extracted decorticated groundnut meal & \\
$\quad(52 \%$ oil and albuminoids or higher) & \\
Finely ground linseed-cake meal & 10 \\
$\quad$ ( $8 \%$ oil or higher) & 8 \\
Meat-and-bone meal (50\% protein) & 20 \\
Minely ground barley meal & 2 \\
\hline
\end{tabular}

Note I. Alternatively finely ground lucerne meal containing not less than $250 \mathrm{mg}$ carotene/kg would be acceptable or, instead of $250 \mathrm{mg}$ carotene $/ \mathrm{kg}$, meal containing at least $19 \%$ protein may be substituted.

Note 2. The mineral supplement shall be of a finely ground nature and steps shall be taken during manufacture to ensure that it is evenly distributed throughout the mix. The analysis of the supplement shall be as follows:

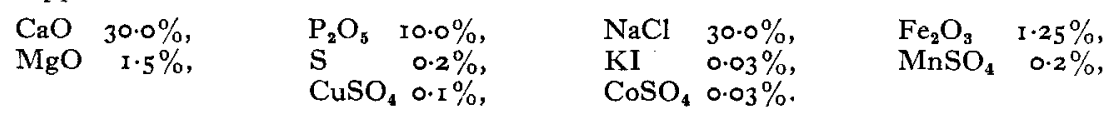

Such precision of description leads to uniformity of batches, particularly in regard to palatability, whether made by this or that compounder, but I will be the 
first to agree that there will be some variation between batches if they are judged by the statutory analyses for oil, albuminoids and fibre.

However, to return to the more simple diets, it must be remembered that it is still impossible in many parts of the world to obtain pelleted concentrate diets and the simple cereal mixtures, usually of local grain and their by-products, could be much improved by the addition of a mineralized protein concentrate, compounded somewhat as follows: white-fish meal (60\% protein) 2 parts, meat-and-bone meal $(50 \%$ protein) 3 parts, linseed-cake meal ( $8 \%$ oil) 3 parts, dried skim milk 2 parts and trace-element mineral mixture 2 parts; added at the rate of $12 \mathrm{lb}$. of this mixture to roo $\mathrm{lb}$. of the cereal mix.

With more adequate concentrated food available breeding results have improved and, in contrast to the figures I have already given, a recent study of 150 unselected litters in each of two similar groups of Dunkin-Hartley guinea-pigs, one mated on a post-partum system and the other mated after weaning of the young, demonstrated that there was improvement in every direction-birth rate, birth weight, survivors to weaning and weaning weight. In addition to Parkes's diet I 8 (modified as in Table $\mathbf{I}$ ) the guinea-pigs were fed hay, kale and water to appetite (Table 2).

Table 2. Breeding performance of Dunkin-Hartley strain guinea-pigs mated post partum and after weaning

(Diet I 8 , hay, kale and water)

\begin{tabular}{|c|c|c|c|c|c|}
\hline $\begin{array}{l}\text { Type of } \\
\text { mating }\end{array}$ & $\begin{array}{l}\text { No. of } \\
\text { litters }\end{array}$ & $\begin{array}{l}\text { Mean no. of } \\
\text { young per } \\
\text { litter born }\end{array}$ & $\begin{array}{l}\text { Mean } \\
\text { weight at } \\
\text { birth } \\
\text { (g) }\end{array}$ & $\begin{array}{l}\text { Mean no. of } \\
\text { young per } \\
\text { litter weaned }\end{array}$ & $\begin{array}{l}\text { Mean } \\
\text { weight at } \\
\text { weaning } \\
\text { (g) }\end{array}$ \\
\hline After weaning & I 50 & 3.98 & 95.0 & 3.94 & 255.8 \\
\hline Post partum & 150 & $3 \cdot 55$ & $96 \cdot 7$ & $3 \cdot 52$ & 250.9 \\
\hline
\end{tabular}

Green food, hay and water may not be as costly as concentrates but they are as important. The need to provide a constant supply of green food, for both breeding and growing stock, has long been recognized. Bruce (r950) has demonstrated that green food is needed to supply vitamin $\mathrm{E}$ as well as vitamin $\mathrm{C}$. The various members of the kale and cabbage families of plants are relished by guinea-pigs and in most places in Britain they can be obtained the year round. The season of real scarcity, April, May and early June, can be bridged with fresh lucerne, grass or chicory. In hard weather when green food is difficult to harvest, many stock keepers feed carrots, beetroots or mangolds, and very useful they are, but it must be remembered that their vitamin $\mathrm{C}$ content is nothing like as high as that of either kale or cabbage and that they do not contain any vitamin E. Failure to maintain adequate green food will eventually produce scurvy, but long before this happens the animal's resistance to infections will be so lowered that it is probable that Pasteurella pseudotuberculosis or Salmonella typhi-murium or other infections will gain a hold on the unit possibly from apparently healthy carrier animals. No diet can be considered adequate unless water is always available and I hope that no worker relies upon moist diets or green food to satisfy the water requirements of his guinea-pigs. 
I would like to mention hay briefly. Some say its importance lies in providing roughage, others suggest a vague 'grass juice factor'. I have come across two distinct trains of signs in breeding stocks deprived of hay. In the first the adults are not affected but the youngsters fade away and die during the $3^{\text {rd }}$ and $4^{\text {th }}$ week of life. In one unit fed on bran and oats and cabbage losses ceased abruptly when quite a small quantity of hay was fed. On many occasions I have seen similar chronic signs in older animals deprived of hay and under varying degrees of experimental stress. The second train of signs was more spectacular and occurred when a group of breeding stock was fed solely on diet I 8 and kale. Briefly, some 2-14 days after parturition, most of the adult females began to slobber (Pl. I, I,2). This was due to the very rapid growth of the teeth which interfered with the movement of the tongue and with deglutition (P1. I, 3,4). The progression of the disease was extremely rapid and within 10-28 days of the onset of signs the animals could no longer move their jaws and the tongue was imprisoned by the overgrown lower molars. From the moment that the animal first showed signs of slobbering its condition deteriorated rapidly as it progressively became less able to bite, to masticate and to swallow its food. The histological picture of the disease was difficult to interpret but my colleague, Dr Joan Ross, reported that the general picture was one of acute rickets complicated mostly by changes typical of scurvy. To make matters more complicated the condition cannot be reproduced at will with any batch of diet 18 and when it does occur a proportion of does will survive and rear their first and even second litters normally before developing signs, whereas others will show signs at the first litter. One female survived through seven pregnancies and reared her youngsters fairly well. We have continued this family through ten generations on diet I 8 and green food, and survival and growth rates have been reasonably good. On the other hand, the youngsters of affected mothers appear healthy but grow very slowly on the hayless diet and, if bred from, will themselves become slobberers. Lack of time and facilities have prevented further study of this condition in recent months but I hope to return to it shortly. Incidentally, finely ground hay meal, made from a sample of hay avidly eaten by guinea-pigs, may be incorporated in a pelleted diet. We have had excellent growth figures recently with diet 18 modified so that twothirds of the grass meal is replaced with palatable high-quality meadow-hay meal containing $14 \%$ protein. Conversely, we have had poor results with a hay meal prepared from hay which looked first class but was not readily eaten in the long state.

Before I close I would seek the help of those present at the meeting regarding the cause and prevention of a disease which occurs in our colonies. I am sure it is dietary in origin and I describe the condition as 'soft-tissue calcification'. Breeding stocks are mainly involved and males are more often affected than females. It occurs mainly in the I 5-2 I months age group, although we have observed it in one female only 28 days old. The morbidity rate is approximately $5 \%$ in boars and $0.5 \%$ in sows. The affected animal appears to shrink, so rapidly does it become thinner and smaller (Pl. 2, I). Quite large spicules of calcium are laid down in the kidney, uterus, seminal vesicles, heart muscle and stomach wall, but the main site is in the 

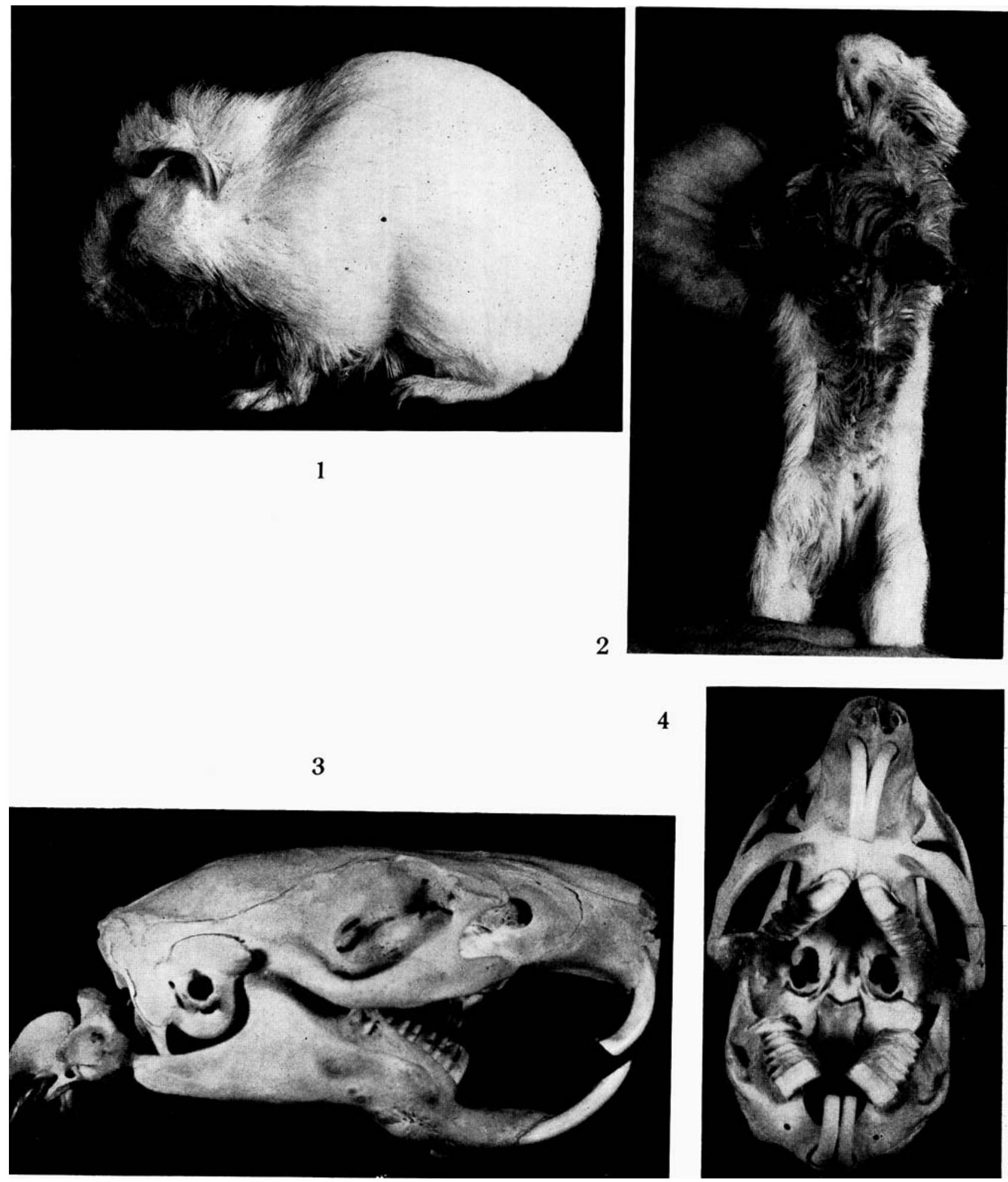

Proceedings of The Nutrition Society, Vol. I6, No. I 

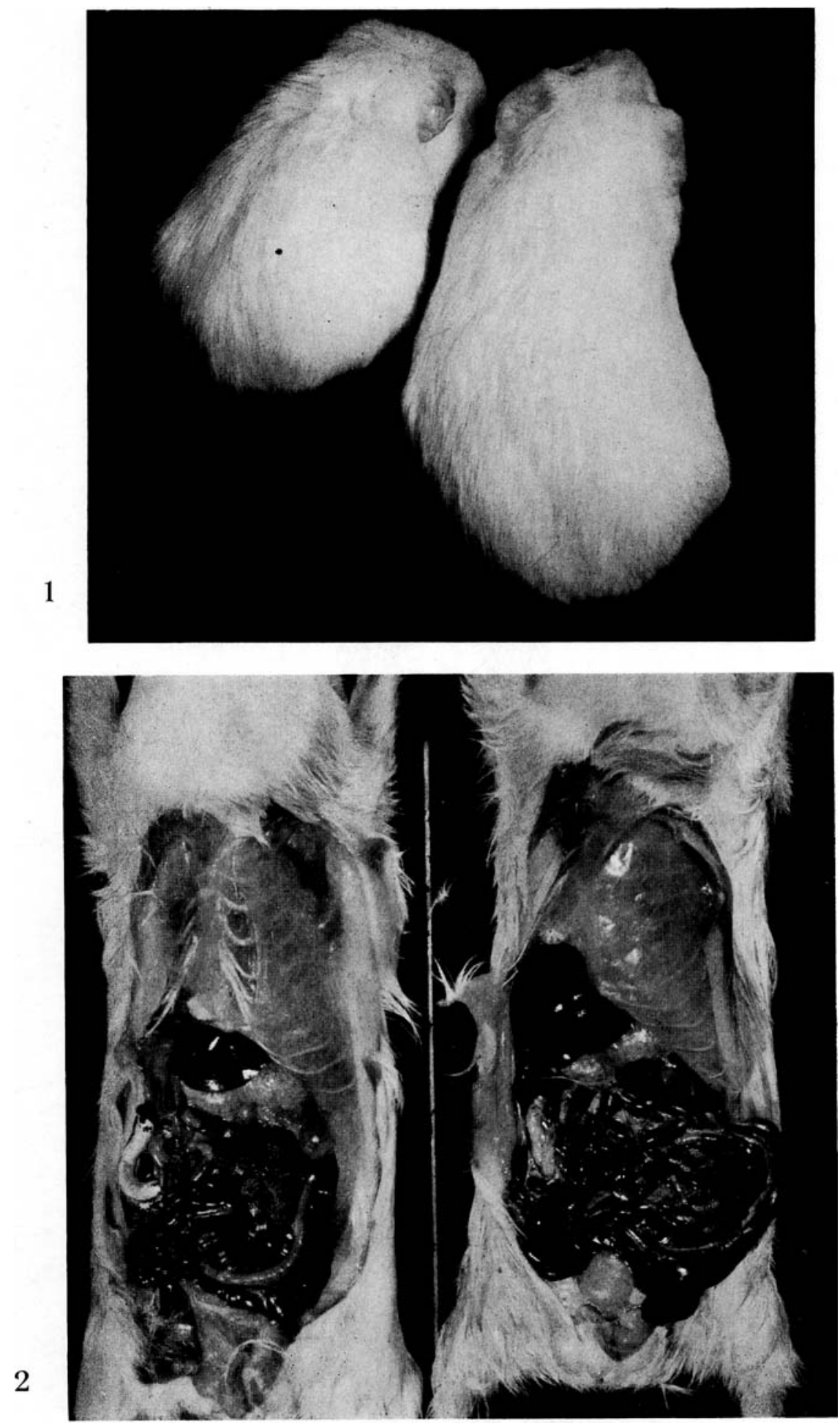

Proceedings of The Nutrition Society, Vol. I6, No. I 
proximal part of the flexure of the small colon which may be so calcified as to appear like the stem of a clay pipe (Pl. 2, 2) with the lumen of the gut almost completely obstructed. Histologically the lesions resemble those characteristic of hypervitaminosis D.

Summarizing, I would say that unless an adequate diet is provided at all times to breeders and growers, the door may be opened to epidemic disease with disastrous results, or the results of experiments will be difficult to interpret if guineapigs matched in weight vary greatly in age or guinea-pigs of the same age vary greatly in physiological development. I would also suggest that the nutritional requirements of the guinea-pig require further study particularly in regard to the part played by hay.

\title{
REFERENCES
}

Bruce, H. M. (1950). \%. Hyg., Camb., 48, 338.

Bruce, H. M. \& Parkes, A. S. (r947). F. Hyg., Camb., 45, 70.

Cassidy, J. (1957). Proc. Nutr. Soc, 16, 63.

Lane-Petter, W. (1957). Proc. Nutr. Soc. 16, 59.

\section{EXPLANATION OF PLATES}

P1. r. Effect of a hay-free diet on guinea-pigs. (I) and (2) Female guinea-pig 2 days after onset of signs. (3) Lateral view of head showing overgrown incisors. (4) Anterior view of skull showing overgrowth of all teeth.

P1. 2. Guinea-pigs with 'soft tissue calcification'. (I) An I 8-month-old male guinea-pig which has shown signs of the disease for 2 weeks (left) compared with a normal male of the same age. (2) Two male guinea-pigs with advanced signs of the disease, particularly in the flexure of the small colon.

\section{Monkey welfare}

\author{
By E. M. Hume, Lister Institute of Preventive Medicine, London, S.W.I
}

\section{Rickets and its prevention}

Outside the tropics monkeys have to be kept largely indoors where the direct sun does not reach them except through glass, and it is indispensable for their welfare as laboratory animals, as zoo exhibits or as pets that they should be properly protected against rickets if they are young animals and against osteomalacia if they are adult. I am not sure how far the battle to prove that is completely won even now. Forty years ago monkeys were said to have cage paralysis when they lost the use of their legs in captivity. That term seems to have disappeared but there is still considerable neglect to provide an adequate supply of vitamin D in some form.

I became interested in monkeys in the First World War when I had a motley collection that I got together at the Lister Institute for our nutritional studies, more particularly on scurvy. The aetiology of rickets was then still uncertain. Sir Edward 